\title{
The Application of Mind Map in ESP Teaching and Learning
}

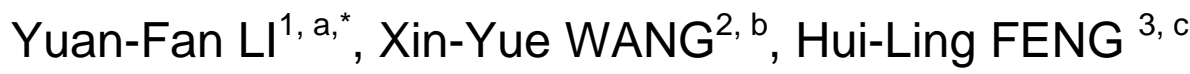

${ }^{1}$ School of Foreign Language, Wuhan Textile University, Hubei, China

${ }^{2,3}$ College of International Business and Economics, Wuhan Textile University, Hubei, China

afannylyflyf@163.com, b20260253@qq.com, ${ }^{\text {c3 } 360289492 @ q q . c o m ~}$

${ }^{*}$ Corresponding author

Keywords: Mind Map, ESP, Teaching and Learning, Application.

\begin{abstract}
In order to make the teaching and learning more effective and efficient, the author applied mind maps in her ESP class. This article aims to discuss the application of mind maps and its positive effects on the teaching and learning in ESP.
\end{abstract}

\section{Introduction}

Since the reform of Chinese College English education, English for Specific Purposes (ESP) has grown to become one of the most prominent areas of EFL teaching today. However, most of the middle schools only teach students general English. And due to different characteristics between English for General Purposes (EGP) and ESP, the teaching and learning of them is not as effective and efficient as expected. The author teaches a module of ESP to designing majors. This module is named Key Concepts and Reflective Practice. The aim of this module is to assist the subject teachers to help the learners understand the concepts of their subject module. Therefore, an important part of this module actually is about ESP teaching and learning. In order to make the teaching and learning more effective and efficient, the author applied Mind Maps in class. This article aims to discuss the application of mind maps and its positive effects on the teaching and learning in ESP.

\section{Definition of ESP and its characteristics}

A very heated debate took place once about whether or not English for Academic Purposes (EAP) could be considered part of ESP in general. Some people described ESP as simply being the teaching of English for any purpose that could be specified. Others, however, were more precise, describing it as the teaching of English used in academic studies or the teaching of English for vocational or professional purposes.

To clarify the meaning of ESP, Dudley-Evans gave an extended definition of ESP in terms of 'absolute' and 'variable' characteristics [1].

\section{Absolute Characteristics}

1. ESP is defined to meet specific needs of the learners

2. ESP makes use of underlying methodology and activities of the discipline it serves

3. ESP is centered on the language appropriate to these activities in terms of grammar, lexis, register, study skills, discourse and genre.

Variable Characteristics

1. ESP may be related to or designed for specific disciplines

2. ESP may use, in specific teaching situations, a different methodology from that of General English

3. ESP is likely to be designed for adult learners, either at a tertiary level institution or in a professional work situation. It could, however, be for learners at secondary school level

4. ESP is generally designed for intermediate or advanced students.

5. Most ESP courses assume some basic knowledge of the language systems 
According to the above definition, EAP can be seen as one branch of ESP. Therefore, in the following article, the author will use ESP to represent both ESP and EAP.

\section{Mind Map}

Mind maps are graphical tools for creating, organizing, representing, and sharing knowledge. They provide visual displays that portray the associations and relationships among facts, terms, concepts, and ideas within a learning task, which are enclosed in circles, ovals, and/or boxes. The geometric shapes utilized in the maps may assist learners to better visualize patterns and discover interrelationships between concepts, which can foster deeper understanding of contents [2]. Each question/idea/concept in a map is called a focus question or central idea. The associations among concepts are indicated by a connecting line linking two concepts. The linking words on the line describe the relationship between the two concepts [3].

The term "mind map" was first popularized by British popular psychology author and television personality Tony Buzan, he suggests the following guidelines for creating mind maps:

1. Start in the center with an image of the topic, using at least 3 colors.

2. Use images, symbols, codes, and dimensions throughout your mind map.

3. Select key words and print using upper or lower case letters.

4. Each word/image is best alone and sitting on its own line.

5. The lines should be connected, starting from the central image. The lines become thinner as they radiate out from the center.

6. Make the lines the same length as the word/image they support.

7. Use multiple colors throughout the mind map, for visual stimulation and also for encoding or grouping.

8. Develop your own personal style of mind mapping.

9. Use emphasis and show associations in your mind map.

10. Keep the mind map clear by using radial hierarchy or outlines to embrace your branches.

Mind maps can be used to structure and classify ideas in personal, educational and business situations as an aid to studying and organizing information. It can be applied in notetaking, brainstorming summarizing. Researches have been done to prove its effectiveness. Cunningham conducted a user study and have found that $80 \%$ of the students thought "mindmapping helped them understand concepts and ideas in science".[4] Other studies also report some subjective positive effects on the use of mind maps. Positive opinions on their effectiveness, however, were much more prominent among students of art and design than in students of computer and information technology, with $62.5 \%$ vs $34 \%$ (respectively) agreeing that they were able to understand concepts better with mind mapping software [5].

\section{The Application of Mind Map in Esp Teaching And Learning}

The author teaches a module of ESP to designing majors. This module is named Key Concepts and Reflective Practice. The aim of this module is to assist the subject teachers to help the learners understand the concepts of their subject module. Therefore, an important part of this module actually is about ESP teaching and learning. In order to make the teaching and learning more effective and efficient, the author applied Mind Maps in class.

\section{The Application of Mind Map in the Teaching and Learning of Esp Vocabulary}

One thing that all of the partners involved in the learning process (students, teachers, materials writers, and researchers) can agree upon is that learning vocabulary is an essential part of mastering a second language. Without grammar very little can be conveyed, without vocabulary nothing can be conveyed [7]. Therefore, to some extent, one's language ability largely depends on his or her size of vocabulary. 
Mind map is introduced to learners and they are asked to draw mind maps which covering the most frequently used terms and key words. Since a mind map is a diagram arranged around a central concept, it can help the learners to grab the connections of the key words thus construct a schema of the topic and related words. In addition, through this way can the learners activate the constructed schemata in their mind about the related topics and vocabulary and bridge the existed knowledge. Therefore, using mind mapping has a positive effect on the teaching and learning of ESP vocabulary.

\section{The Application of Mind Map in the Teaching and Learning of Esp Reading}

In essence, a mind map has four essential characteristics: (1) the map's subject is highlighted in a central image; (2) the primary themes of the subject radiate from the central image as branches; (3) branches include a key image or key word printed on an associated line; and (4) topics of lesser importance are also presented as branches attached to higher level branches [6].

Due to these characteristics, in the teaching and learning of ESP passages, mind mapping can help learners to form a global understanding of the topic and construct the connections among key factors and elements thus acquire a thorough understanding of the passages.

\section{Other Application of Mind Map In the Teaching and Learning of Esp}

Besides is positive effects on the teaching and learning of ESP vocabulary and reading, it also has a positive impact on the teaching and learning of ESP speaking and writing. Since vocabulary and reading are receptive learning, mind mapping help learners to form and construct connections among concepts which leads to an effective input, speaking and writing are productive learning, mind mapping help learners to brainstorm ideas around the central topic which leads to an effective output.

\section{Conclusion}

In order to make the teaching and learning more effective and efficient, the author applied Mind Maps in her class called Key Concepts and Reflective Practice. This article has discussed abouthow to draw a mind map and its application and positive effects on the teaching and learning in ESP. To conclude, using mind maps does have positive effects on the teaching and learning of ESP vocabulary, reading, speaking and writing for mind mapping helps learners to construct concepts and form and activate schemata. The effects of different types of mind maps should be studied in further research.

\section{Acknowledgement}

This research was supported jointly by the Teaching Research Project of Wuhan Textile University (Grant No. 201705049) and the Undergraduate Training Program for Innovation and Entrepreneurship of Hubei Provincial Department of Education (Grant No. 201713240001) and Wuhan Textile University (Grant No. 201704083).

\section{References}

[1]T.Dudley-Evans,Developments in English for Specific Purposes: A multi-disciplinary approach. Cambridge University Press, 1998.

[2]N.Strangman, T.Hall and A.Meyer, Graphicorganizers and implications for universal design forlearning: Curriculum enhancement report.Wakefield, MA: National Center on Accessing the GeneralCurriculum, 2003.

[3]J. D.Novak,A. J.Canas, The theory underlying concept maps and how to construct and use them, 2008.Retrieved from https://wenku.baidu.com/view/d26542bcc77da26925c5b0a0.html

[4] G. E. Cunningham, Mindmapping: Its Effects on Student Achievement in High School Biology (Ph.D.), the University of Texas at Austin (2005). 
[5] B. Holland, L. Holland, J. Davies, An investigation into the concept of mind mapping and the use of mind mapping software to support and improve student academic performance (2004).

[6] B. K. Nong, T. P. Anh, and Tran, T. N. M.. "Integrate the digital mindmapping into teaching and learning psychology.” Proc., 13th UNESCO-APEID Int. Conf. on Education and World Bank-KERISHigh Level Seminar on ICT in Education, Hangzhou Department of Education and Xiacheng People’s Government, Hangzhou, China (2009).

[7] D. A. Wilkins, Linguistics in Language Teaching. Cambridge: MA: MIT Press, 1972. 